\title{
molecules
}

ISSN 1420-3049

www.mdpi.com/journal/molecules

Article

\section{Germacranes and $m$-Menthane from Illicium lanceolatum}

Ming Zhao ${ }^{1,2, *}$, Xianming Zhang ${ }^{3}$, Yan Wang ${ }^{4, *}$, Min Huang ${ }^{4}$, Jin-Ao Duan ${ }^{5}$,

Tanja Gödecke ${ }^{1,2}$, Karina M. Szymulanska-Ramamurthy ${ }^{1,2}$, Zhiqi Yin ${ }^{1,2,6}$ and Chun-Tao Che ${ }^{1,2}$

1 Department of Medicinal Chemistry and Pharmacognosy, College of Pharmacy, University of Illinois at Chicago, Chicago, IL 60612, USA; E-Mails: tan13ja@gmail.com (T.G.); kszymu2@uic.edu (K.M.S.-R.); chyzq2005@126.com (Z.Y.); chect@uic.edu (C.-T.C.)

2 WHO Collaborative Center for Traditional Medicine, College of Pharmacy, University of Illinois at Chicago, Chicago, IL 60612, USA

3 Department of Pharmacology, College of Medicine, University of Illinois at Chicago, Chicago, IL 60612, USA; E-Mail: zhangxm1973@gmail.com

4 State Key Laboratory of Bioactive Substance and Function of Natural Medicines, Institute of Materia Medica, Chinese Academy of Medical Science and Peking Union Medical College, Beijing 100050, China; E-Mail: Huangmin@imm.ac.cn

5 Jiangsu Key Laboratory for TCM Formulae Research, Nanjing University of Traditional Chinese Medicine, Nanjing 210046, China; E-Mail: Duanja@163.com

6 Department of Natural Medicinal Chemistry, China Pharmaceutical University, Nanjing 210009, China

* Authors to whom correspondence should be addressed; E-Mails: mingz@uic.edu (M.Z.); wangyan@imm.ac.cn (Y.W.); Tel.: +1-312-996-1557 (M.Z.); +86-10-6316-5238 (Y.W.); Fax: +1-312-996-7107 (M.Z.).

Received: 15 March 2014; in revised form: 27 March 2014 / Accepted: 28 March 2014 / Published: 4 April 2014

\begin{abstract}
Three new germacrane sesquiterpenes and a new $m$-menthane monoterpene were isolated together with four known compounds from the pericarp of Illicium lanceolatum, an adulterant to star anise (Illicium verum). All compounds were isolated from Illicium plants for the first time. The absolute stereochemistry of all germacranes and $m$-menthane was established by a combination of NMR and the modified Mosher's ester method. The biological activity was evaluated on SH-SY5Y neuroblastoma cell line. $(1 S, 5 R, 7 R)-1,5$-Dihydroxygermacra-4(15),10(14),11(12)-triene (at $62.5 \mu \mathrm{M}$ ) and $(1 R, 5 R, 7 R)$-1,5-dihydroxygermacra-4(15),10(14),11(12)-triene (at $15.6 \mu \mathrm{M})$ promoted the
\end{abstract}


proliferation of SH-SY5Y by $36.2 \%$ and $45.8 \%$, respectively, after $48 \mathrm{~h}$ incubation, indicating potential neurotrophic activity.

Keywords: Illicium lanceolatum; Illiciaceae; germacrane sesquiterpenes; m-menthane monoterpene; absolute stereochemistry; proliferative promotion; $\mathrm{SH}-\mathrm{SY} 5 \mathrm{Y}$

\section{Introduction}

The genus Illicium L. (Illiciaceae) consists of ca. 40 species that form one of the earliest evolutionary branches of the angiosperms [1]. This small taxon is represented by evergreen trees and shrubs disjunctively distributed in North America, Mexico, Peru, the West Indies and eastern Asia, with the highest concentration of species found in northern Myanmar and southern China [1,2]. The most well-known member of this genus is probably Illicium verum. It serves as the source material of shikimic acid in the production of oseltamivir (Tamiflu) [3], and its ripe pericarps (known as star anise) are widely used as a spice in many countries in Asia, in particular, China, India, and Vietnam [4]. I. verum also has a long history of medicinal applications in China [5]. In Mexico and the southwestern United States, its fruits are used to make herbal tea to alleviate colic of babies and stomach aches $[4,6]$. However, in recent years, intoxication cases related to the culinary and medicinal use of star anise have been reported, associating with neurological effects such as seizures, vomiting, jitteriness, rapid eye movement, and even death [7-9]. Follow-up investigations indicated that most, if not all, of the adverse effects were caused by adulterated toxic Illicium plants. Phytochemical and biological studies pointed to seco-prezizaane sesquiterpenes (such as anisatin and neoanisatin) to be the toxic ingredients [10-12]. The toxicological mechanism was elucidated to be a picrotoxin-like, noncompetitive antagonism to the $\gamma$-aminobutyric acid (GABA) receptor [13-16]. However, systematic studies of the structure-toxicity relationship are limited [17-19]. To safeguard the use of star anise and its products, studies on adulterant species of Illicium is warranted.

Apart from the potential toxicity, some ingredients of Illicium plants are known to display neurotrophic properties. Among others, jiadifenin, jiadifenolide, illicinin A, and 4-allyl-2,6-dimethoxy3-(3-methylbut-2-enyl)phenol have been reported to promote neurite outgrowth in primary cultures of fetal rat cortical neurons [20-23]. Illicium plants are thus considered a potential source of neurotrophin-like natural products.

We are interested in constructing a library of secondary metabolites of Illicium plants, to identify toxic components on one hand, and search for neurotrophin-mimic natural products on the other. Several Illicium species are being investigated in our group. As part of the studies, I. lanceolatum, a toxic adulterant of Chinese star anise, was investigated for its chemical composition. This paper reports the structures of four germacrane sesquiterpenes (including three new structures), a new $m$-menthane monoterpene, and three other known compounds, and their biological activities in the SH-SY5Y neuroblastoma cell line. 


\section{Results and Discussion}

From the pericarps of I. lanceolatum, repeated open column (silica gel, RP-18, MCI, and Sephadex LH-20) and semi-preparative chromatographic separations resulted in the purification of four germacrane sesquiterpenes 1-4, and a $m$-menthane monoterpene 5 (Figure 1), together with three other known compounds 6-8. Germacrane 4 was a known compound, but its absolute stereochemistry was newly established in the present work.

Figure 1. Structures of compounds 1-5.

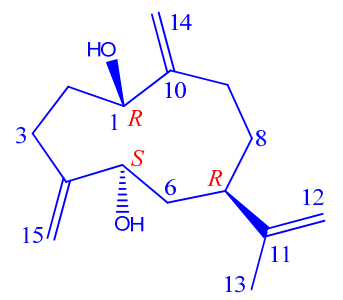

(1)

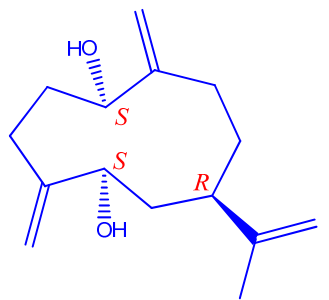

(2)

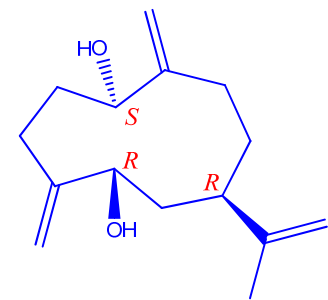

(3)

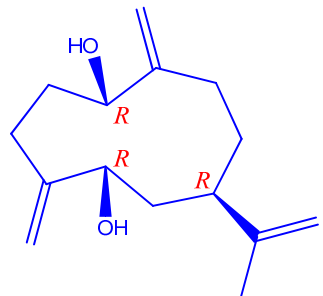

(4)

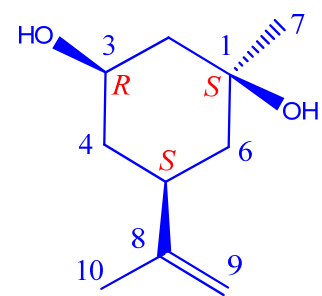

(5)

Compound 1 was obtained as a white amorphous powder. A molecular formula of $\mathrm{C}_{15} \mathrm{H}_{24} \mathrm{O}_{2}$ was determined based on the HR-ESI-MS result at $\mathrm{m} / z$ 219.1733 $\left[\mathrm{M}-\mathrm{H}_{2} \mathrm{O}+\mathrm{H}\right]^{+}$(calcd. 219.1743), indicating four degrees of unsaturation. The ${ }^{1} \mathrm{H}-,{ }^{13} \mathrm{C}$ - and DEPT-NMR spectra (Tables 1 and 2) indicated the presence of one methyl, eight methylenes (including three olefinic ones), three methines (including two oxygenated groups), and three quaternary olefinc carbons. The presence of three double bonds accounted for three degrees of unsaturation, the remaining one was therefore deduced arising from a ring structure in the molecule.

In the ${ }^{1} \mathrm{H}-{ }^{1} \mathrm{H}$ COSY spectrum, signals at $\delta_{\mathrm{H}} 1.98$ and $2.10(\mathrm{~m}, \mathrm{H}-2)$ displayed correlations with signals at $\delta_{\mathrm{H}} 4.24(\mathrm{dd}, J=5.2,10.5 \mathrm{~Hz}, \mathrm{H}-1)$ and $\delta_{\mathrm{H}} 2.29(\mathrm{~m}, \mathrm{H}-3)$, respectively, suggesting the presence of structural fragment $1 \mathrm{a}$ (Figure 2). The correlations of $\delta_{\mathrm{H}} 1.83(\mathrm{~m}, \mathrm{H}-6)$ with $\delta_{\mathrm{H}} 4.36$ (dd, $J=3.9,7.0 \mathrm{~Hz}, \mathrm{H}-5)$ and $\delta_{\mathrm{H}} 2.68(\mathrm{~m}, \mathrm{H}-7)$, and that of $\delta_{\mathrm{H}} 1.68(\mathrm{~m}, \mathrm{H}-8)$ with $\delta_{\mathrm{H}} 2.68(\mathrm{~m}, \mathrm{H}-7)$ and $\delta_{\mathrm{H}}$ 2.04 (m, H-9), led to the establishment of fragment $\mathbf{1 b}$ (Figure 2). In the HMBC (Figure 3), the cross peaks between $\delta_{\mathrm{H}} 1.76(\mathrm{~s}, \mathrm{H}-13)$ and $\delta_{\mathrm{C}} 39.7(\mathrm{CH}, \mathrm{C}-7), \delta_{\mathrm{C}} 151.3(\mathrm{C}, \mathrm{C}-11)$ and $\delta_{\mathrm{C}} 110.3\left(\mathrm{CH}_{2}, \mathrm{C}-12\right)$ suggested a partial structure 1c (Figure 2). The connection of 1a and 1c via two exocyclic double bonds was established based on the following evidence: long-range correlations between $\delta_{\mathrm{H}} 5.16$ (s, $\mathrm{H}-14)$ and $77.2(\mathrm{CH}, \mathrm{C}-1)$ and $29.8\left(\mathrm{CH}_{2}, \mathrm{C}-9\right)$; as well as those between $\delta_{\mathrm{H}} 5.13 / 5.02$ (both s, H-15) and $72.5(\mathrm{CH}, \mathrm{C}-5)$ and $29.2\left(\mathrm{CH}_{2}, \mathrm{C}-3\right)$. All available evidence led to the planar structure 1d (Figure 2), belonging to germacrane sesquiterpene.

To determine the absolute configuration of C-1 and C-5, the modified Mosher ester procedure was employed $[24,25]$. Thus, treatment with $(R)$ - and $(S)$-MTPA chlorides led to esterification of 1-OH and 5-OH, affording $(S)$ - and $(R)$-MTPA derivatives, respectively. The ${ }^{1} \mathrm{H}-\mathrm{NMR}$ chemical shift differences $\left(\Delta \delta_{S-R}\right)$ were observed (1, Figure 4). The absolute configuration of C-1 and C-5 were consequently determined to be $R$ and $S$, respectively. In the NOESY spectrum, $\delta_{\mathrm{H}} 2.68(\mathrm{~m}, \mathrm{H}-7)$ correlated with $\delta_{\mathrm{H}}$ 4.24 (dd, $J=5.2,10.5 \mathrm{~Hz}, \mathrm{H}-1$ ), suggesting the $R$-configuration of C-7. Thus, 1 was identified to be $(1 R, 5 S, 7 R)$-1,5-dihydroxygermacra-4(15),10(14),11(12)-triene. To the best of our knowledge, it is the first time a germacrane sesquiterpene is isolated from Illicium plants. 
Table 1. ${ }^{13} \mathrm{C}-\mathrm{NMR}$ spectroscopic data for compounds $\mathbf{1}-\mathbf{4}\left(\mathrm{CD}_{3} \mathrm{OD}, 100 \mathrm{MHz}\right)$.

\begin{tabular}{|c|c|c|c|c|}
\hline No. & 1 (mult.) & 2 (mult.) & 3 (mult.) & 4 (mult.) \\
\hline 1 & $77.2(\mathrm{C})$ & $70.6(\mathrm{C})$ & $74.1(\mathrm{C})$ & $75.3(\mathrm{C})$ \\
\hline 2 & $33.9\left(\mathrm{CH}_{2}\right)$ & $33.5\left(\mathrm{CH}_{2}\right)$ & $34.4\left(\mathrm{CH}_{2}\right)$ & $33.5\left(\mathrm{CH}_{2}\right)$ \\
\hline 3 & $29.2\left(\mathrm{CH}_{2}\right)$ & $26.7\left(\mathrm{CH}_{2}\right)$ & $27.0\left(\mathrm{CH}_{2}\right)$ & $25.8\left(\mathrm{CH}_{2}\right)$ \\
\hline 4 & $152.7(\mathrm{C})$ & $152.2(\mathrm{C})$ & $153.6(\mathrm{C})$ & $151.6(\mathrm{C})$ \\
\hline 5 & $72.5(\mathrm{CH})$ & $74.6(\mathrm{CH})$ & $76.7(\mathrm{CH})$ & $77.3(\mathrm{CH})$ \\
\hline 6 & $41.1\left(\mathrm{CH}_{2}\right)$ & $40.6\left(\mathrm{CH}_{2}\right)$ & $40.1\left(\mathrm{CH}_{2}\right)$ & $37.8\left(\mathrm{CH}_{2}\right)$ \\
\hline 7 & $39.7(\mathrm{CH})$ & $40.8(\mathrm{CH})$ & $42.1(\mathrm{CH})$ & $42.2(\mathrm{CH})$ \\
\hline 8 & $30.4\left(\mathrm{CH}_{2}\right)$ & $30.1\left(\mathrm{CH}_{2}\right)$ & $31.5\left(\mathrm{CH}_{2}\right)$ & $33.4\left(\mathrm{CH}_{2}\right)$ \\
\hline 9 & $29.8\left(\mathrm{CH}_{2}\right)$ & $35.2\left(\mathrm{CH}_{2}\right)$ & $32.1\left(\mathrm{CH}_{2}\right)$ & $31.4\left(\mathrm{CH}_{2}\right)$ \\
\hline 10 & $150.6(\mathrm{C})$ & $152.1(\mathrm{C})$ & $151.7(\mathrm{C})$ & $150.6(\mathrm{C})$ \\
\hline 11 & $151.3(\mathrm{C})$ & $150.7(\mathrm{C})$ & $150.4(\mathrm{C})$ & $150.5(\mathrm{C})$ \\
\hline 12 & $110.3\left(\mathrm{CH}_{2}\right)$ & $110.5\left(\mathrm{CH}_{2}\right)$ & $110.4\left(\mathrm{CH}_{2}\right)$ & $110.5\left(\mathrm{CH}_{2}\right)$ \\
\hline 13 & $20.1\left(\mathrm{CH}_{3}\right)$ & $20.5\left(\mathrm{CH}_{3}\right)$ & $19.0\left(\mathrm{CH}_{3}\right)$ & $19.4\left(\mathrm{CH}_{3}\right)$ \\
\hline 14 & $116.9\left(\mathrm{CH}_{2}\right)$ & $113.8\left(\mathrm{CH}_{2}\right)$ & $114.3\left(\mathrm{CH}_{2}\right)$ & $114.4\left(\mathrm{CH}_{2}\right)$ \\
\hline 15 & $112.4\left(\mathrm{CH}_{2}\right)$ & $111.4\left(\mathrm{CH}_{2}\right)$ & $112.8\left(\mathrm{CH}_{2}\right)$ & $114.9\left(\mathrm{CH}_{2}\right)$ \\
\hline
\end{tabular}

Table 2. ${ }^{1} \mathrm{H}-\mathrm{NMR}$ Spectroscopic Data for Compounds 1-4 $\left(\mathrm{CD}_{3} \mathrm{OD}, 400 \mathrm{MHz}\right)$.

\begin{tabular}{lllll}
\hline No. & $\mathbf{1}$ [mult., $\boldsymbol{J}(\mathbf{H z})]$ & $\mathbf{2}$ [mult., $\boldsymbol{J}(\mathbf{H z})]$ & $\mathbf{3}$ [mult., $\boldsymbol{J}(\mathbf{H z})]$ & $\mathbf{4}$ [mult., $\boldsymbol{J}(\mathbf{H z})]$ \\
\hline 1 & $4.24 \mathrm{dd}(5.2,10.5)$ & $4.23 \mathrm{dd}(4.5,9.6)$ & $4.11 \mathrm{dd}(4.2,10.4)$ & $4.16 \mathrm{dd}(4.1,9.6)$ \\
2 & $2.10 \mathrm{~m} ; 1.98 \mathrm{~m}$ & $2.22 \mathrm{~m} ; 1.95 \mathrm{~m}$ & $2.25 \mathrm{~m} ; 1.82 \mathrm{~m}$ & $2.09 \mathrm{~m} ; 1.56 \mathrm{~m}$ \\
3 & $2.29 \mathrm{~m}$ & $2.38 \mathrm{dd}(4.0,11.4) ; 2.07 \mathrm{~m}$ & 2.11 (overlap) & $2.32 \mathrm{dd}(4.0,14.2) ; 2.07 \mathrm{~m}$ \\
5 & $4.36 \mathrm{dd}(3.9,7.0)$ & $4.31 \mathrm{dd}(3.5,5.9)$ & $3.88 \mathrm{t}(7.8)$ & $3.92 \mathrm{dd}(3.9,11.4)$ \\
6 & $1.83 \mathrm{~m}$ & $1.91 \mathrm{ddd}(2.3,6.4,14.2) ; 1.69$ (overlap) & 1.67 (overlap) & $1.85 \mathrm{ddd}(2.7,11.3,14.0) ; 1.59 \mathrm{~m}$ \\
7 & $2.68 \mathrm{~m}$ & $2.42 \mathrm{~m}$ & 2.11 (overlap) & $2.17 \mathrm{~m}$ \\
8 & $1.68 \mathrm{~m}$ & $1.74 \mathrm{~m} ; 1.53 \mathrm{~m}$ & $1.61 \mathrm{~m}$ & $1.96 \mathrm{~m} ; 1.64 \mathrm{~m}$ \\
9 & $2.45 \mathrm{~m} ; 2.04 \mathrm{~m}$ & $2.20 \mathrm{~m} ; 2.13 \mathrm{dd}(3.0,11.2)$ & 2.14 (overlap) & $2.42 \mathrm{~m} ; 2.05 \mathrm{~m}$ \\
12 & $4.77 \mathrm{~s}$ & $4.73 \mathrm{~s} ; 4.69 \mathrm{~s}$ & $4.66 \mathrm{br} \mathrm{s}$ & $4.69 \mathrm{~s} ; 4.68 \mathrm{~s}$ \\
13 & $1.76 \mathrm{~s}$ & $1.70 \mathrm{~s}$ & $1.67 \mathrm{~s}$ & $1.69 \mathrm{~s}$ \\
14 & $5.16 \mathrm{~s} ; 4.95 \mathrm{~s}$ & $5.19 \mathrm{~s} ; 5.03 \mathrm{~s}$ & $5.24 \mathrm{~s} ; 5.02 \mathrm{~s}$ & $5.18 \mathrm{~s} ; 5.02 \mathrm{~s}$ \\
15 & $5.13 \mathrm{~s} ; 5.02 \mathrm{~s}$ & $5.05 \mathrm{~s} ; 4.98 \mathrm{~s}$ & $5.12 \mathrm{~s} ; 5.05 \mathrm{~s}$ & $5.02 \mathrm{br} \mathrm{s}$ \\
\hline
\end{tabular}

Figure 2. Partial structures of $\mathbf{1}$.

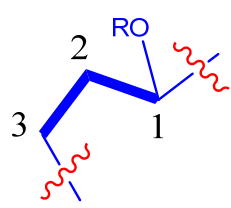

(1a)

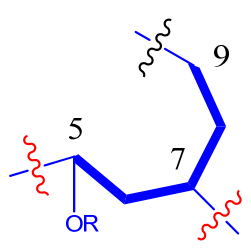

(1b)

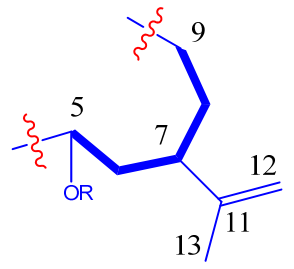

(1c)

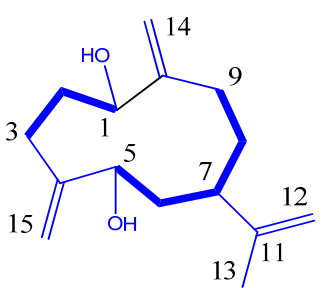

(1d) 
Figure 3. Selected ${ }^{1} \mathrm{H}^{-1} \mathrm{H} \operatorname{COSY}(-)$ and $\operatorname{HMBC}(\rightarrow)$ correlations of compounds $\mathbf{1}-\mathbf{3}, \mathbf{5}$.

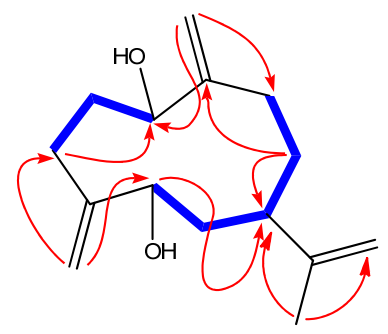

1

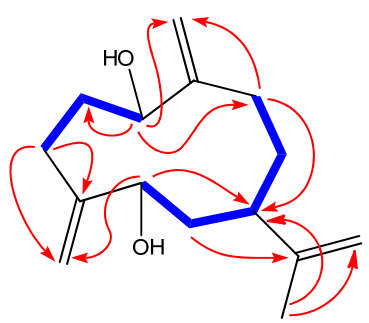

2

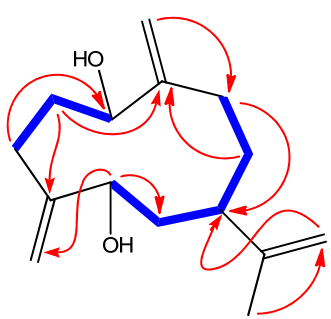

3

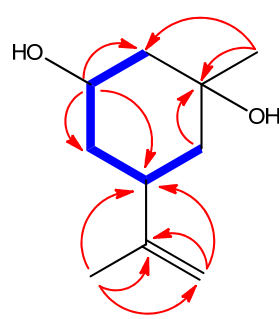

5

Figure 4. $\Delta \delta_{\mathrm{S}-\mathrm{R}}$ values of MTPA esters of 1-5.

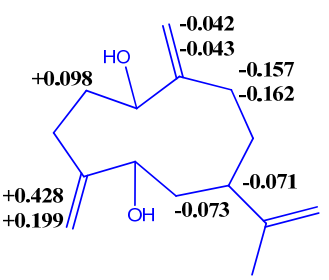

1

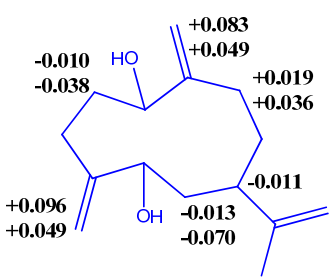

2

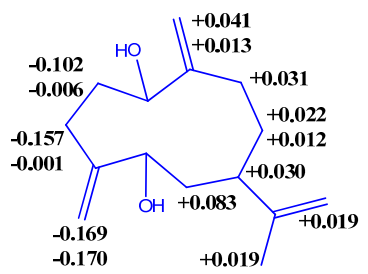

3

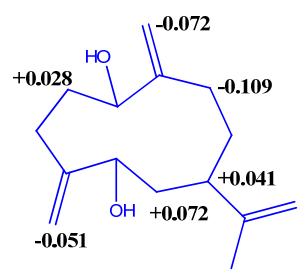

4

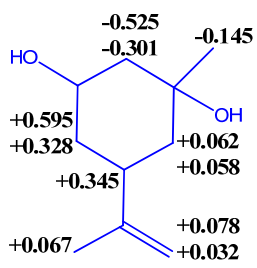

5

Compounds 2, 3, and 4 were stereoisomers of $\mathbf{1}$. By using the same strategies as in the structural elucidation of $\mathbf{1}$, compounds $\mathbf{2}, \mathbf{3}$, and $\mathbf{4}$ were identified to be $(1 S, 5 S, 7 R)$-1,5-dihydroxygermacra4(15),10(14),11(12)-triene, $\quad(1 S, 5 R, 7 R)$-1,5-dihydroxygermacra-4(15),10(14),11(12)-triene, and $(1 R, 5 R, 7 R)$-1,5-dihydroxygermacra-4(15),10(14),11(12)-triene (Figures 1 and 4), respectively. In the NOESY spectrum of $2, \delta_{\mathrm{H}} 1.70(\mathrm{~s}, \mathrm{H}-13)$ correlated with $\delta_{\mathrm{H}} 4.31(\mathrm{dd}, J=3.5,5.9, \mathrm{H}-5)$, indicating the $\alpha$-orientation of H-7. For compound 3, due to the unresolved overlap of the $\mathrm{H}-7$ signal in $\mathrm{CD}_{3} \mathrm{OD}$, NOESY spectrum was further acquired in $\mathrm{CDCl}_{3}$ for the assignment of relative configuration of $\mathrm{H}-7$. The $\alpha$-orientation of H-7 was suggested by the NOESY correlation between $\mathrm{H}-7$ and $5 \alpha-\mathrm{H}$. While the $\alpha$-orientation of H-7 in 4 was suggested by the NOESY correlation from $\delta_{\mathrm{H}} 2.17(\mathrm{~m}, \mathrm{H}-7)$ to both $\delta_{\mathrm{H}} 4.16(\mathrm{dd}, J=4.1,9.6, \mathrm{H}-1)$ and $\delta_{\mathrm{H}} 3.92(\mathrm{dd}, J=3.9,11.4, \mathrm{H}-5)$. Compound 4 is a known structure, previously reported from Gonospermum elegans but with undetermined absolute configuration [26].

Compound 5 was obtained as a white amorphous powder. A molecular formula of $\mathrm{C}_{10} \mathrm{H}_{18} \mathrm{O}_{2}$ was determined based on the HRESIMS result at $m / z$ 193.1202 [M $+\mathrm{Na}]^{+}$(calcd. 193.1199), indicating two degrees of unsaturation. The ${ }^{1} \mathrm{H}-,{ }^{13} \mathrm{C}$ - and DEPT-NMR spectra (Table 3 ) revealed the presence of two methyls, four methylenes (including one olefinic ones), two methines (including one oxygenated group), and two quaternary carbons (including an olefinic one). All proton signals were assignable based on the gHSQC experiment (Table 3). The ${ }^{1} \mathrm{H}-{ }^{1} \mathrm{H}$ COSY spectrum displayed correlations between $\delta_{\mathrm{H}} 1.72(\mathrm{H}-2)$ and $\delta_{\mathrm{H}} 3.60(\mathrm{~d}, J=3.16 \mathrm{~Hz}, \mathrm{H}-3)$, between $\delta_{\mathrm{H}} 3.60(\mathrm{H}-3)$ and $\delta_{\mathrm{H}} 1.91(\mathrm{ddd}, J=2.8,11.6$, $14.0 \mathrm{~Hz}, \mathrm{H}-4 \mathrm{a})$ and $\delta_{\mathrm{H}} 1.63(\mathrm{dt}, J=3.4,13.8 \mathrm{~Hz}, \mathrm{H}-4 \mathrm{~b})$, between $\delta_{\mathrm{H}} 1.91(\mathrm{H}-4 \mathrm{a})$ and $\delta_{\mathrm{H}} 2.23(\mathrm{~m}, \mathrm{H}-5)$, between $\delta_{\mathrm{H}} 2.23(\mathrm{H}-5)$ and $\delta_{\mathrm{H}} 1.53(\mathrm{H}-6)$, leading to the connections of between $\mathrm{C}_{2}-\mathrm{C}_{3}-\mathrm{C}_{4}-\mathrm{C}_{5}-\mathrm{C}_{6}$ (Figures 1 and 3). The HMBC correlations between $\delta_{\mathrm{H}} 1.69(\mathrm{~s}, 10-\mathrm{H})$ and $\delta_{\mathrm{C}} 37.4(\mathrm{C}-5), \delta_{\mathrm{C}} 109.0(\mathrm{C}-9)$, and $\delta_{\mathrm{C}} 149.2(\mathrm{C}-8)$, as well as correlations between $\delta_{\mathrm{H}} 4.70$ (br s, H-9) and $\delta_{\mathrm{C}} 21.1(\mathrm{C}-10), \delta_{\mathrm{C}} 37.4(\mathrm{C}-5)$, and $\delta_{\mathrm{C}} 149.2(\mathrm{C}-8)$, suggested that $\mathrm{C}-9$ and $\mathrm{C}-10$ were connected to $\mathrm{C}-5$ via $\mathrm{C}-8$ (Figures 1 and 3 ). The remaining part of the structure was established based on the following long-range correlations: $\delta_{\mathrm{H}} 1.53$ $(\mathrm{H}-6) / \delta_{\mathrm{C}} 71.4(\mathrm{C}-1) ; \delta_{\mathrm{H}} 1.23(\mathrm{~s}, \mathrm{H}-7) / \delta_{\mathrm{C}} 71.4(\mathrm{C}-1)$ and $\delta_{\mathrm{C}} 33.7(\mathrm{C}-2)$. Two hydroxyl groups were 
assigned to $\mathrm{C}-1$ and $\mathrm{C}-3$, respectively. In the NOESY spectrum, $\delta_{\mathrm{H}} 2.23(\mathrm{~m}, \mathrm{H}-5)$ displayed correlations with $\delta_{\mathrm{H}} 3.60(\mathrm{~d}, J=3.2 \mathrm{~Hz}, \mathrm{H}-3)$, and $\delta_{\mathrm{H}} 1.23(\mathrm{~s}, \mathrm{H}-7)$, indicating the relative stereochemistry of $1 \beta, 3 \beta$-dihydroxy- $(5 \alpha \mathrm{H})$ - $m$-menth- 8 -ene. To determine the absolute stereochemistry, modified Mosher's ester procedure was carried out. Due to the steric hindrance on C-1, only 3-OH was esterified by $(R)$ - and $(S)$-MTPA chlorides into $(S)$ - and $(R)$-MTPA derivatives. The absolute configuration of C-3 was finally deduced to be $R$ based on the proton shift difference between $(S)$ - and $(R)$-MTPA derivatives (5, Figure 4), indicating a $3 \alpha-\mathrm{H}$. The $1 S$ - and $5 S$-configuration were then assignable based on the NOESY results mentioned above. Consequently, 5 was determined to be $(1 S, 3 R, 5 S)$-1,3-dihydroxy-m-menth-8-ene.

Table 3. ${ }^{13} \mathrm{C}$ - and ${ }^{1} \mathrm{H}-\mathrm{NMR}$ spectroscopic data for compound $\mathbf{5}\left(\mathrm{CDCl}_{3}\right) *$.

\begin{tabular}{lll}
\hline No. & $\boldsymbol{\delta}_{\mathbf{C}}$ (mult.) & $\boldsymbol{\delta}_{\mathbf{H}}$ [mult., $\left.\boldsymbol{J}(\mathrm{Hz})\right]$ \\
\hline 1 & $71.4(\mathrm{C})$ & - \\
2 & $33.7\left(\mathrm{CH}_{2}\right)$ & 1.72 (partial overlap); 1.49 (partial overlap) \\
3 & $73.8(\mathrm{CH})$ & $3.60 \mathrm{~d}(3.2)$ \\
4 & $34.0\left(\mathrm{CH}_{2}\right)$ & $1.91 \mathrm{ddd}(2.8,11.6,14.0) ; 1.63 \mathrm{dt}(3.4,13.8)$ \\
5 & $37.4(\mathrm{CH})$ & $2.23 \mathrm{~m}$ \\
6 & $26.1\left(\mathrm{CH}_{2}\right)$ & 1.53 (partial overlap) \\
7 & $26.5\left(\mathrm{CH}_{3}\right)$ & $1.23 \mathrm{~s}$ \\
8 & $149.2(\mathrm{C})$ & - \\
9 & $109.0\left(\mathrm{CH}_{2}\right)$ & $4.70 \mathrm{br} \mathrm{s}$ \\
10 & $21.1\left(\mathrm{CH}_{3}\right)$ & $1.69 \mathrm{~s}$ \\
\hline \multicolumn{3}{c}{$* 100 \mathrm{MHz}$ for ${ }^{13} \mathrm{C}$ and $400 \mathrm{MHz}$ for ${ }^{1} \mathrm{H}$, respectively. }
\end{tabular}

Compounds 6, 7, and $\mathbf{8}$ were identified to be 3-hydroxyocta-1,5E-dien-7-one [27], 2-(4-methylphenyl)-1,2-propanediol [28], and trans-3,4,5-trimethoxycinnamic alcohol [29], respectively, based on the interpretation of their NMR spectroscopic data and comparison with reported data. 6, 7, and $\mathbf{8}$ were isolated from Illicium plants for the first time.

Compounds 3 and $\mathbf{4}$ exhibited proliferative activity in SH-SY5Y cells at concentrations of $0.49 \mu \mathrm{M}-125 \mu \mathrm{M}$. Compounds 3 (at $62.5 \mu \mathrm{M}$ ) and 4 (at $15.6 \mu \mathrm{M}$ ) could promote proliferation by $36.2 \%$ and $45.8 \%$ after 48 -h incubation, respectively. Compounds 5-8 were inactive; $\mathbf{6}$ and $\mathbf{8}$ displayed cytotoxicity at the concentrations above $50 \mu \mathrm{M}$. Due to the scarcity of $\mathbf{1}$ and $\mathbf{2}$, they were not tested for the bioactivity. Efforts to obtained additional crops of these compounds are in progress.

\section{Experimental}

\subsection{General}

The FT-IR spectra $(\mathrm{KBr})$ were recorded using a Thermo FT-IR Nicolet 5700. Optical rotations at sodium D line were measured with a Perkin-Elmer 241 digital polarimeter using quartz cell with a path length of $100 \mathrm{~mm}$ at room temperature. Concentrations (c) are given in $\mathrm{g} / 100 \mathrm{~mL}$. Nuclear magnetic resonance (NMR) spectra were recorded on a Bruker DPX-400 or AVANCE-400 spectrometer running at $400 \mathrm{MHz}$ for ${ }^{1} \mathrm{H}$ and $100 \mathrm{MHz}$ for ${ }^{13} \mathrm{C}$, respectively. All chemical shifts were quoted on the $\delta$ scale in ppm using residual solvent as the internal standard $\left(\mathrm{CDCl}_{3}: 7.24 \mathrm{ppm}\right.$ for ${ }^{1} \mathrm{H}-\mathrm{NMR}$, 
$77.0 \mathrm{ppm}$ for ${ }^{13} \mathrm{C}-\mathrm{NMR}$; $\mathrm{CD}_{3} \mathrm{OD}: 3.30 \mathrm{ppm}$ for ${ }^{1} \mathrm{H}-\mathrm{NMR}, 49.0 \mathrm{ppm}$ for ${ }^{13} \mathrm{C}-\mathrm{NMR} ; \mathrm{C}_{5} \mathrm{D}_{5} \mathrm{~N}: 8.71 \mathrm{ppm}$, $7.55 \mathrm{ppm}, 7.19 \mathrm{ppm}$ for ${ }^{1} \mathrm{H}-\mathrm{NMR}, 149.9 \mathrm{ppm}, 135.5 \mathrm{ppm}, 123.5 \mathrm{ppm}$ for $\left.{ }^{13} \mathrm{C}-\mathrm{NMR}\right)$. Coupling constants $(J)$ are reported in Hz. The following abbreviations are used to indicate the multiplicity: $\mathrm{s}=$ singlet, $\mathrm{d}=$ doublet, $\mathrm{t}=$ triple, $\mathrm{dd}=$ double doublet, $\mathrm{dt}=$ double triplet, $\mathrm{br}=$ broad. Thin layer chromatography (TLC) was carried out using Merck aluminium backed sheets coated with 60F254 silica gel or 60F254 RP-silica gel. Visualization of the plates was achieved by using a UV lamp $\left(\lambda_{\max }=254 \mathrm{~nm}\right)$, and spraying a mixture of $2 \% p$-hydroxybenzaldehyde methanolic solution and $5 \%$ sulphuric acid ethanolic solution $(10: 1, v / v)$ followed by heating. Open column chromatography was carried out on columns packed with silica gel, RP silica gel $\left(\mathrm{C}_{18}\right)$ (Macherey-Nagel GmbH \& Co. KG, Düren, Germany), MCI gel CPH 20 (Supelco, Sigma-Aldrich, Bellefonte, PA, USA), and Sephadex LH-20 (GE Healthcare Bio-Sciences AB, Uppsala, Sweden). For HPLC purification, a $\mathrm{C}_{18}$ semi-preparative HPLC column (Phenomenex $\mathrm{C}_{18}$ column, $250 \times 10 \mathrm{~mm}, 5 \mu \mathrm{m}$ ) and a Shimadzu UFLC system were used; the UV detection wavelength and flow rate were set at $U_{210 \mathrm{~nm}}$ and $4 \mathrm{~mL} / \mathrm{min}$, respectively. A Shimadzu UFLC XR system coupled with a LCMS-2020 liquid chromatography mass spectrometer was used for sample analysis. All solvents used were analytical or HPLC grade. HRESIMS were measured on a Shimadzu LCMS-IT-TOF Mass Spectrometry.

\subsection{Plant Material}

The pericarps of Illicium lanceolatum A. C. Smith. were collected from An-hui Province, China, in October 2011, and were identified by one of the authors (Jin-Ao Duan). A voucher specimen was deposited in the Department of Medicinal Chemistry and Pharmacognosy (UICMCP001-Ilan-P), College of Pharmacy, University of Illinois at Chicago, Chicago, IL, USA.

\subsection{Extraction and Isolation}

The dried pericarps of Illicium lanceolatum $(1 \mathrm{~kg})$ were powdered and extracted by percolation with methanol (MeOH, $15 \mathrm{~L})$, yielding $300 \mathrm{~g}$ of extract. The extract was applied to a silica gel flash column eluted with mixtures of petroleum ether (PE)-ethyl acetate (EA) (100:0 $\rightarrow$ 50:50), followed by dichloromethane (DCM)-MeOH $(90: 10,85: 15$, and $0: 100)$, to yield 40 fractions $\left(\mathrm{A}_{1}-\mathrm{A}_{40}\right)$. The fractions after $\mathrm{A}_{35}\left(\mathrm{~A}_{35}\right.$ : elute of $\left.\mathrm{DCM}-\mathrm{MeOH}, 85: 15\right)$ contained plenty of shikimic acid. Fraction $\mathrm{A}_{17}$ was further fractionated into 23 fractions $\left(\mathrm{B}_{1}-\mathrm{B}_{23}\right)$ on a silica gel column eluted with mixtures of PE-EA (70:30 and 60:40). $\mathrm{B}_{11}$ was subjected to RP-18 chromatography eluted with aqueous $\mathrm{MeOH}$ (20\% and $100 \%)$ to yield 15 fractions $\left(\mathrm{C}_{1}-\mathrm{C}_{15}\right)$. Compound $6(6.1 \mathrm{mg})$ was purified from fractions of $\mathrm{C}_{4}$ and $\mathrm{C}_{5}$ by Sephadex LH-20 chromatography (eluted with $30 \%$ aqueous $\mathrm{MeOH}$ ). Fractions of $\mathrm{C}_{8}-\mathrm{C}_{14}$ were combined and subjected to Sephadex LH-20 chromatography (eluted with 30\% aqueous $\mathrm{MeOH}$ ) to obtain a mixture $(>100 \mathrm{mg}$ ) of compounds 5 and 7. An aliquot of the mixture was purified by semi-preparative HPLC using 30\% aqueous acetonitrile (AcCN) as mobile phase to yield compounds 5 ( $>50 \mathrm{mg}$ ), and 7 (5 mg). Fractions $\mathrm{A}_{20}-\mathrm{A}_{22}$ were further fractionated into 25 subfractions $\left(\mathrm{D}_{1}-\mathrm{D}_{25}\right)$ on a MCI column eluted with aqueous methanol $(10 \% \rightarrow 100 \%)$. $\mathrm{D}_{14}$ and $\mathrm{D}_{15}$ were subjected to Sephadex LH-20 chromatography (eluted by $\mathrm{MeOH}$ ) to yield 20 fractions $\left(\mathrm{E}_{1}-\mathrm{E}_{20}\right)$. Compound 8 (18 mg) was purified from $\mathrm{E}_{13}-\mathrm{E}_{15}$ by semi-preparative HPLC separation (35\% aqueous AcCN). $E_{7}$ and $E_{8}$ were further subjected to a silica gel column eluted with mixtures of PE-EA 
$(80: 0 \rightarrow 65: 35)$ to yield 32 fractions $\left(F_{1}-F_{32}\right)$. There were three main components in fractions of $\mathrm{F}_{13}-\mathrm{F}_{16}$. They were purified by semi-preparative HPLC chromatography (35\% aqueous $\left.\mathrm{MeOH}\right)$ to yield compounds $1(2.5 \mathrm{mg}), \mathbf{2}(2.2 \mathrm{mg})$. Compounds $3(15 \mathrm{mg})$ and $4(50 \mathrm{mg})$ were purified from $\mathrm{F}_{17}-\mathrm{F}_{26}$ by semi-preparative HPLC chromatography (35\% aqueous $\left.\mathrm{MeOH}\right)$.

\subsection{Spectral Data}

(1R,5S,7R)-1,5-Dihydroxygermacra-4(15),10(14),11(12)-triene (1). White amorphous powder. IR $\left(\mathrm{cm}^{-1}\right): 3377,2989,1703,1576,1405,1081 .[\alpha]_{\mathrm{D}}^{20}-3^{\circ}(c 0.12, \mathrm{MeOH}) .{ }^{13} \mathrm{C}$ - and ${ }^{1} \mathrm{H}-\mathrm{NMR}$ spectroscopic data $\left(\mathrm{CD}_{3} \mathrm{OD}\right)$ : see Tables 1 and 2, respectively. HR-ESI-MS $m / z 219.1733\left[\mathrm{M}-\mathrm{H}_{2} \mathrm{O}+\mathrm{H}\right]^{+}$(calcd. for $\left.\mathrm{C}_{15} \mathrm{H}_{23} \mathrm{O}, 219.1743\right), m / z 201.1639\left[\mathrm{M}-2 \mathrm{H}_{2} \mathrm{O}+\mathrm{H}\right]^{+}$.

(1S,5S,7R)-1,5-Dihydroxygermacra-4(15),10(14),11(12)-triene (2). Colorless oil. IR ( $\left.\mathrm{cm}^{-1}\right)$ : 3359, 2928, 1641, 1439, 1015, 895. [ $\alpha]_{\mathrm{D}}^{20}-7^{\circ}(c \quad 0.14, \mathrm{MeOH}) .{ }^{13} \mathrm{C}-$ and ${ }^{1} \mathrm{H}-\mathrm{NMR}$ spectroscopic data $\left(\mathrm{CD}_{3} \mathrm{OD}\right.$ ): see Tables 1 and 2, respectively. HR-ESI-MS $m / z 219.1735\left[\mathrm{M}-\mathrm{H}_{2} \mathrm{O}+\mathrm{H}\right]^{+}$(calcd. for $\left.\mathrm{C}_{15} \mathrm{H}_{23} \mathrm{O}, 219.1743\right), 201.1630\left[\mathrm{M}-2 \mathrm{H}_{2} \mathrm{O}+\mathrm{H}\right]^{+}$.

(1S,5R,7R)-1,5-Dihydroxygermacra-4(15),10(14),11(12)-triene (3). White amorphous powder. IR $\left(\mathrm{cm}^{-1}\right): 3260,2928,1644,1434,1020,905 .[\alpha]_{\mathrm{D}}^{20}-4^{\circ}(c 0.17, \mathrm{MeOH}) .{ }^{13} \mathrm{C}$ - and ${ }^{1} \mathrm{H}-\mathrm{NMR}$ spectroscopic data $\left(\mathrm{CD}_{3} \mathrm{OD}\right)$ : see Tables 1 and 2, respectively. ${ }^{1} \mathrm{H}$ spectroscopic data $\left(\mathrm{CDCl}_{3}, 400 \mathrm{~Hz}\right): \delta_{\mathrm{H}} 5.24(1 \mathrm{H}$, s, H-14a), 5.03 (1H, s, H-14b); $5.16(1 \mathrm{H}, \mathrm{s}, \mathrm{H}-15 \mathrm{a}), 5.06$ (1H, s, H-15b); 4.65 (1H, s, H-12a), $4.64(1 \mathrm{H}$, s, H-12b); $4.16(1 \mathrm{H}, \mathrm{dd}, J=4.3,10.2 \mathrm{~Hz}, \mathrm{H}-1) ; 3.95(1 \mathrm{H}, \mathrm{dd}, J=5.0,10.7 \mathrm{~Hz}, \mathrm{H}-5) ; 2.27$ (1H, m, $\mathrm{H}-2 \mathrm{a}), 1.83$ (1H, m, H-2b); 2.13 (4H, overlapped, $\mathrm{H}-3$ and $\mathrm{H}-9) ; 2.06$ (1H, t, $J=5.7 \mathrm{~Hz}, \mathrm{H}-7) ; 1.73$ $(1 \mathrm{H}, \mathrm{t}, J=5.2 \mathrm{~Hz}, \mathrm{H}-6 \mathrm{a}), 1.59(1 \mathrm{H}$, partially overlapped, H-6b); 1.58 (2H, partially overlapped, H-8a; 1.65 (3H, s, H-13). HR-ESI-MS $m / z 219.1734\left[\mathrm{M}-\mathrm{H}_{2} \mathrm{O}+\mathrm{H}\right]^{+}$(calcd. for $\mathrm{C}_{15} \mathrm{H}_{23} \mathrm{O}, 219.1743$ ), 201.1642 $\left[\mathrm{M}-2 \mathrm{H}_{2} \mathrm{O}+\mathrm{H}\right]^{+}, 237.1820[\mathrm{M}+\mathrm{H}]^{+}$.

(1R,5R,7R)-1,5-Dihydroxygermacra-4(15),10(14),11(12)-triene (4). Colorless oil. IR ( $\left.\mathrm{cm}^{-1}\right)$ : 3368, 2927, 1642, 1449, 1012, 893. $[\alpha]_{\mathrm{D}}^{20}+11^{\circ}\left(c\right.$ 0.16, MeOH). ${ }^{13} \mathrm{C}$ - and ${ }^{1} \mathrm{H}-\mathrm{NMR}$ spectroscopic data $\left(\mathrm{CD}_{3} \mathrm{OD}\right)$ : see Tables 1 and 2, respectively. HR-ESI-MS $m / z 219.1740\left[\mathrm{M}-\mathrm{H}_{2} \mathrm{O}+\mathrm{H}\right]^{+}$(calcd. for $\mathrm{C}_{15} \mathrm{H}_{23} \mathrm{O}$, 219.1743), 201.1650 [M-2 $\left.\mathrm{H}_{2} \mathrm{O}+\mathrm{H}\right]^{+}$.

(1S,3R,5S)-1,3-Dihydroxy-m-menth-8-ene (5). White amorphous powder. ${ }^{13} \mathrm{C}$ - and ${ }^{1} \mathrm{H}-\mathrm{NMR}$ spectroscopic data $\left(\mathrm{CDCl}_{3}\right.$ ): see Table 3. HR-ESI-MS $m / z$ 193.1202 [M+Na] ${ }^{+}$(calcd. for $\mathrm{C}_{10} \mathrm{H}_{18} \mathrm{O}_{2} \mathrm{Na}, 193.1199$ ).

\subsection{Preparation of the (R)- and (S)-MTPA Ester Derivatives of 1-5}

In these experiments, $(R)$ - and $(S)$-MTPA chloride was used to react with each compound to yield its $(S)$ - and $(R)$-MTPA derivatives, respectively [25]. Two aliquots of compound (0.5-1.0 mg each) were transferred into two NMR tubes and dried overnight in a desiccator with $\mathrm{P}_{2} \mathrm{O}_{5}$ inside. After successive addition of $6 \mu \mathrm{L}$ of $(R)$ - or $(S)$-MTPA chloride and $600 \mu \mathrm{L}$ of pyridine- $d_{5}$, the NMR tubes were sealed immediately, and shaken vigorously. The tubes were then kept in desiccator overnight until the reaction was complete [30]. The ${ }^{1} \mathrm{H}-\mathrm{NMR}$ spectra of the final $(R)$ - and $(S)$-MTPA derivatives were recorded, and the chemical shifts were assigned based on the ${ }^{1} \mathrm{H}-{ }^{1} \mathrm{H}$ COSY NMR experiments. In 
case that signals could not be unambiguously assigned, gHSQC and gHMBC experiments were carried out. The $\Delta \delta_{S-R}$ values were calculated [24,25].

\subsection{In Vitro Assay on SH-SY5Y}

The SH-SY5Y cells were maintained in the Opti-MEM with $10 \% \mathrm{FBS}, 100 \mathrm{U} / \mathrm{mL}$ penicillin and $100 \mu \mathrm{g} / \mathrm{mL}$ streptomycin. The cells $\left(5 \times 10^{4}\right.$ or $1 \times 10^{5} /$ well in $1 \mathrm{~mL}$ growth medium $)$ were incubated with various concentrations of compounds in 24-well culture plates. After 48 -h incubation, $20 \mu \mathrm{L}$ MTT (3-(4,5-dimethylthiazol-2yl)-2.5-diphenyltetrazolium bromide, $5 \mathrm{mg} / \mathrm{mL}$ in PBS) were added to the each well. The supernatant were removed after further $4 \mathrm{~h}$ incubation. The formazan in each well were dissolved in $300 \mu \mathrm{L}$ isopropanol with $4 \mathrm{mM} \mathrm{HCl}$ and $0.1 \%$ Nondet P-40. The absorbance was read at $590 \mathrm{~nm}$ with a reference filter of $620 \mathrm{~nm}$ by using microplate reader (Infinite M200 Pro, Tecan, San Jose, CA, USA). The cells without treatment were as vehicle control. The cells were treated by corresponding concentration of DMSO as control. The percentage of growth promotion was calculated using the following formula: \% cell promotion $=100 \times\left(\mathrm{OD}_{590 \mathrm{~nm} \text { test compound }}-\mathrm{OD}_{590 \mathrm{~nm} \text { control }}\right) / \mathrm{OD}_{590 \mathrm{~nm} \text { control }}$. Results were expressed as the mean of at least three independent experiments.

\section{Conclusions}

Three new germacrane sesquiterpenes 1-3, a new $m$-menthane monoterpene 5, together with a known germacrane sesquiterpene 4, and three other known compounds 6-8 have been identified from I. lanceolatum. All the compounds were isolated from Illicium plants for the first time. Absolute stereochemistry for germacranes and $m$-menthane were established. Compounds $\mathbf{3}$ and $\mathbf{4}$ exhibited proliferative activity on the SH-SY5Y cell lines, indicating potential neurotrophic activity. Further biological evaluation on primary cultures of fetal rat cortical neurons is under planning.

\section{Supplementary Materials}

Supplementary materials can be accessed at: http://www.mdpi.com/1420-3049/19/4/4326/s1.

\section{Acknowledgments}

The project was supported by the National Mega-project for Innovative Drugs (Grants 2012ZX09301-002-001, 2012ZX09301-002-006) and the State Key Laboratory of Bioactive Substances and Functions of Natural Medicines Open Project (No. GTZK201310). The authors gratefully acknowledge Shi-hui Dong for his valuable suggestion on the determination of absolute configuration. Colleagues of Jin-Ao Duan are thanked for collection the plant materials; Aleksei Krunic is acknowledged for his skillful assistance in acquiring NMR data. The Authors are grateful for the technical support from the Analytical Center of the Peking Branch of Japanese Shimadzu Corporation.

\section{Author Contributions}

Ming Zhao carried out the isolation, purification, and structural elucidation of natural products, and prepared the manuscript. Xianming Zhang contributed to the bioassay test. Karina M. Szymulanska-Ramamurthy and Zhiqi Yin helped in modified Mosher's ester reactions and 
interpretation. Yan Wang, Min Huang, and Tanja Gödecke were responsible for the physical data collection and NMR data acquisition. Jin-Ao Duan collected and authenticated the plant materials. Chun-Tao Che supervised the whole research project.

\section{Conflicts of Interest}

The authors declare no conflict of interest.

\section{References}

1. Jordal, M.M. Illicium, Pimpinella and Foeniculum; CRC Press LLC: Boca Raton, FL, USA, 2004.

2. Kubo, M.; Shima, N.; Harada, K.; Hioki, H.; Fukuyama, Y. New prenylated C6-C3 compounds from the twigs of Illicium anisatum. Chem. Pharm. Bull. 2011, 59, 898-901.

3. Estevez, A.M.; Estevez, R.J. A short overview on the medicinal chemistry of (-)-shikimic acid. Mini-Rev. Med. Chem. 2012, 12, 1443-1454.

4. Wang, G.-W.; Hu, W.-T.; Huang, B.-K.; Qin, L.-P. Illicium verum: A review on its botany, traditional use, chemistry and pharmacology. J. Ethnopharmacol. 2011, 136, 10-20.

5. Editorial Committee of Chinese Pharmacopoeia. Chinese Pharmacopoeia, 2010 ed.; China Medical Science and Technology Press: Beijing, China, 2010.

6. Ize-Ludlow, D.; Ragone, S.; Bruck Isaac, S.; Bernstein Jeffrey, N.; Duchowny, M.; Pena Barbara, M.G. Neurotoxicities in infants seen with the consumption of star anise tea. Department of Pediatrics, Miami Children's Hospital, Miami, FL 33155, USA; United States FIELD Citation, 2004; pp. e653-e656.

7. Garzo Fernandez, C.; Gomez Pintado, P.; Barrasa Blanco, A.; Martinez Arrieta, R.; Ramirez Fernandez, R.; Ramon Rosa, F. Cases of neurological symptoms associated with star anise consumption used as a carminative. An. Esp. Pediatr. 2002, 57, 290-294.

8. Johanns, E.S.D.; van der Kolk, L.E.; van Gemert, H.M.A.; Sijben, A.E.J.; Peters, P.W.J.; de Vries, I. An epidemic of epileptic seizures after consumption of herbal tea. Ned. Tijdschr. Geneeskd. 2002, 146, 813-816.

9. Xu, X.R. The authentication of Star Anise and toxic Illicium lanceolatum. Qilu Yaoshi 1984, 3, $27-28$.

10. Lane, J.F.; Koch, W.T.; Leeds, N.S.; Gorin, G. The toxin of Illicium anisatum. I. The isolation and characterization of a convulsant principle: Anisatin. J. Am. Chem. Soc. 1952, 74, 3211-3214.

11. Yamada, K.; Takada, S.; Nakamura, S.; Hirata, Y. Structures of anisatin and neoanisatin toxic sesquiterpenes from Illicium anisatum. Tetrahedron 1968, 24, 199-229.

12. Yang, C.; Hashimoto, M.; Baba, N.; Takahshi, M.; Kaneto, H.; Kawano, N.; Kouno, I. A new toxic neoanisatin derivative from the pericarps of Illicium majus. Chem. Pharm. Bull. 1990, 38, 291-292.

13. Ikeda, T.; Ozoe, Y.; Okuyama, E.; Nagata, K.; Honda, H.; Shono, T.; Narahashi, T. Anisatin modulation of the $\gamma$-aminobutyric acid receptor-channel in rat dorsal root ganglion neurons. $B r . J$. Pharmacol. 1999, 127, 1567-1576. 
14. Kakemoto, E.; Okuyama, E.; Nagata, K.; Ozoe, Y. Interaction of anisatin with rat brain $\gamma$-aminobutyric acidA receptors: Allosteric modulation by competitive antagonists. Biochem. Pharmacol. 1999, 58, 617-621.

15. Kudo, Y.; Oka, J.; Yamada, K. Anisatin, a potent GABA antagonist, isolated from Illicium anisatum. Neurosci. Lett. 1981, 25, 83-88.

16. Matsumoto, K.; Fukuda, H. Anisatin modulation of GABA- and pentobarbital-induced enhancement of diazepam binding in rat brain. Neurosci. Lett. 1982, 32, 175-179.

17. Kuriyama, T.; Schmidt, T.J.; Okuyama, E.; Ozoe, Y. Structure-activity relationships of seco-prezizaane terpenoids in $\gamma$-aminobutyric acid receptors of houseflies and rats. Bioorg. Med. Chem. 2002, 10, 1873-1881.

18. Schmidt, T.J.; Gurrath, M.; Ozoe, Y. Structure-activity relationships of seco-prezizaane and picrotoxane/picrodendrane terpenoids by quasar receptor-surface modeling. Bioorg. Med. Chem. 2004, 12, 4159-4167.

19. Schmidt, T.J.; Okuyama, E.; Fronczek, F.R. The molecular structure of $2 \alpha$-hydroxyneoanisatin and structure-activity relationships among convulsant sesquiterpenes of the seco-prezizaane and picrotoxane types. Bioorg. Med. Chem. 1999, 7, 2857-2865.

20. Kubo, M.; Okada, C.; Huang, J.-M.; Harada, K.; Hioki, H.; Fukuyama, Y. Novel pentacyclic seco-prezizaane-type sesquiterpeneoids with neurotrophic properties from Illicium jiadifengpi. Org. Lett. 2009, 11, 5190-5193.

21. Takaoka, S.; Takaoka, N.; Minoshima, Y.; Huang, J.-M.; Kubo, M.; Harada, K.; Hioki, H.; Fukuyama, Y. Isolation, synthesis, and neurite outgrowth-promoting activity of illicinin A from the flowers of Illicium anisatum. Tetrahedron 2009, 65, 8354-8361.

22. Trzoss, L.; Xu, J.; Lacoske, M.H.; Mobley, W.C.; Theodorakis, E.A. Enantioselective synthesis of (-)-jiadifenin, a potent neurotrophic modulator. Org. Lett. 2011, 13, 4554-4557.

23. Yokoyama, R.; Huang, J.-M.; Yang, C.-S.; Fukuyama, Y. New seco-prezizaane-type sesquiterpenes, jiadifenin with neurotrophic activity and 1,2-dehydroneomajucin from Illicium jiadifengpi. J. Nat. Prod. 2002, 65, 527-531.

24. Ohtani, I.; Kusumi, T.; Kashman, Y.; Kakisawa, H. High-field FT NMR application of Mosher's method. The absolute configurations of marine terpenoids. J. Am. Chem. Soc. 1991, 113, 4092-4096.

25. Rieser, M.J.; Hui, Y.H.; Rupprecht, J.K.; Kozlowski, J.F.; Wood, K.V.; McLaughlin, J.L.; Hanson, P.R.; Zhuang, Z.; Hoye, T.R. Determination of absolute configuration of stereogenic carbinol centers in annonaceous acetogenins by proton and fluorine 19-NMR analysis of Mosher ester derivatives. J. Am. Chem. Soc. 1992, 114, 10203-10213.

26. Triana, J.; Lopez, M.; Rico, M.; Gonzalez-Platas, J.; Quintana, J.; Estevez, F.; Leon, F.; Bermejo, J. Sesquiterpeneoid derivatives from Gonospermum elegans and their cytotoxic activity for HL-60 human promyelocytic cells. J. Nat. Prod. 2003, 66, 943-948.

27. Bohlmann, F.; Gupta, R.K.; Jakupovic, J.; King, R.M.; Robinson, H. Naturally occurring terpene derivatives. Part 338. Eudesmanolides and heliangolides from Calea rotundifolia. Phytochemistry 1981, 20, 1635-1637.

28. Matsumoto, T.; Ishida, T.; Takeda, Y.; Yagi, J. The enantioselective metabolism of 4-isopropenyltoluene in rabbits. Biol. Pharm. Bull. 1994, 17, 1441-1445. 
29. Matsuura, H.; Miyazaki, H.; Asakawa, C.; Amano, M.; Yoshihara, T.; Mizutani, J. Isolation of a-glucosidase inhibitors from hyssop (Hyssopus officinalis). Phytochemistry 2004, 65, 91-97.

30. Dong, S.-H.; Nikolic, D.; Simmler, C.; Qiu, F.; van Breemen, R.B.; Soejarto, D.D.; Pauli, G.F.; Chen, S.-N. Diarylheptanoids from Dioscorea villosa (Wild Yam). J. Nat. Prod. 2012, 75, $2168-2177$.

Sample Availability: Samples of the compound 3, 4, and 5-8 are available from the authors.

(C) 2014 by the authors; licensee MDPI, Basel, Switzerland. This article is an open access article distributed under the terms and conditions of the Creative Commons Attribution license (http://creativecommons.org/licenses/by/3.0/). 